\title{
Finite Element Simulation to study the effect of flank wear land inclination on Cutting forces and temperature distribution in orthogonal machining
}

\author{
VISHALDATT V KOHIR* \\ Associate Professor, Department of Mechanical Engineering, Angadi Institute of Technology \\ and Management, Savagaon, Belgaum, Karnataka, India
}

\section{S T DUNDUR}

Professor, Department of Industrial and Production Engineering, Basaveshawar Engineering college, Bagalkot, Karnataka, India

\begin{tabular}{ll}
\hline \hline Article history & Flank wear greatly influences the economics of the cutting \\
Received: & operations as it is related to the prediction of tool life of the cutting \\
& tool. The initial geometry of the tool alters with progress of the \\
Received in revised form: & flank wear. It has been experimentally proved that flank wear land \\
22.12 .2014 & is not parallel to the cutting direction. This paper investigates the \\
& effect of length and inclination of the flank wear land on the cutting \\
Accepted: & forces, effective stress and temperature distribution using finite \\
23.12.2014 & element simulations. Finite element modeling is preferred in the \\
Key words: & present investigation, as it consumes less time and cost compare to \\
\hline $\begin{array}{l}\text { Defor M 2D, Flank wear land } \\
\text { inclination, RSM, FEM, }\end{array}$ & $\begin{array}{l}\text { empirical or analytical modeling and capable of providing } \\
\text { Simulation, ANOVA }\end{array}$ \\
& $\begin{array}{l}\text { information about the distribution of performance measures. } \\
\text { DEFORM 2D, a widely used software tool employed for modeling } \\
\text { and simulating the orthogonal machining process with different } \\
\text { levels of wear lengths and inclinations. The results of the study } \\
\text { shows that, the flank wear land inclination has higher influence on } \\
\text { the thrust force compare to wear land length. The length and } \\
\text { inclination of flank wear land effects the maximum temperature in } \\
\text { tool. }\end{array}$
\end{tabular}

\footnotetext{
Correspondence: vishalkohir@gmail.com
} 



\section{Introduction}

Various modeling methods are used to model the metal cutting process. Those can be summarized as empirical models, analytical models, mechanistic model, finite element models and artificial intelligence based models [1]. With the upgrading of computational ability of computer, the finite element modeling method has become handy in recent times. The Finite Element Method (FEM) provides very close results to the real values and therefore, it is now a well accepted numerical method [2]. The verified performance of the FEM simulations motivated the present research community to opt it for modeling of the metal cutting process [3].

FEM based simulations offers a lot of advantages compared to analytical models. The finite element cutting simulation is capable of estimating process variables which cannot be measured easily or directly during machining process such as normal stress, tool temperature, temperature of chip, effective stress, strain and strain rate. The knowledge of these process variables is essential to have an insight of the mechanics of cutting process and to conduct tool wear analysis [4].Some of the works are reported below;

Nicoleta Lungu, Marian Borzan [3] performed finite element simulation to know the effect of cutting speed and feed on the geometry of the tool, temperature and cutting forces in machining of AISI 1045 work material using Deform 2D machining software. The input parameters of machining, cutting speed and feed were varied without altering the geometry of the tool. Based on the results of simulation it was observed that while cutting with high feed rate both cutting forces and temperature were found to increase, causing alteration of the tool geometry. This indicates presence of higher wear rate.

The friction prevailing at the contact surface between chip and tool rake face plus friction at contact surface between tool and work plays an important role in the machining process. Some researchers believe Sliding friction law (Merchant, Lee and Shaffer) and others believe adhesion friction (Trent, Maekawa, Das and Dundur) appropriately governs the chip-tool and tool-work contact regions [5].Understanding the significance of the friction coefficient during machining $\mathrm{K}$. GÖK, A. GÖK and M. Erdem [6] investigated the effects of friction factor on temperature and pressure at tool-chip interface. In their study, AISI 1020 workpiece material and carbide (\%15 cobalt) type Cutting tool was used. The three levels of friction factors (0.6-0.81.2) were used for simulating the machining process by keeping cutting speed, depth of cut and feed rate constant. The simulation results show that the increase in the coefficient of friction increases the temperature and the cutting pressure at the tool-chip contacts. ANSYS/LS-DYNA software was employed to simulate the orthogonal cutting process with different cutting tool geometries, varying rake and edge radius by J.Zouhar and M.Piska [7]. The models were developed based on Lagrangian formulation. In this study Johnson-Cook plasticity equation was used to model the work material and Johnson Cook damage rule was used for the chip separation. They observed, that the enhancement in cutting forces were mainly because of increase in rake angle, but an increase in tool edge radius results in lesser force increase. K Khalili M Safaei [8] conducted the finite element analysis of chamfered tools. They investigated the effects of width of chamfer and angle on machining forces, tool stresses, maximum temperature at the tool tip, contour of the shear zone and effective stresses. The 
AISI 1045 steel, following Oxley's equation for flow stress, available in the material library was used as work piece material. The simulation results show that the velocity of the work material around the dead metal zone is almost stagnant and the velocity of material below the flank wear is equivalent to the work velocity. This difference in velocity is the indication of high degree of straining of the material below the flank wear land and existence of large friction at the interface of flank wear land and machined surface. The chamfer width and angle has more effect on the thrust force compare to cutting force. Senthil Kumar and T.Tamizharasan [9] studied the effects of tool geometries in machining AISI 1045steel. The different tool shape such as C,D and $\mathrm{S}$ were modeled in the Solid works software and then imported into the DEFORM-2D software environment for simulation of machining. The machining parameters like cutting speed, feed rate and depth of cut were kept constant and geometrical parameters like insert shape, nose radius and side clearance angle were altered. Simulations were planned as per Taguchi's L9 orthogonal array with three parameters at three levels. Results of simulations show that when the nose radius increases the wear depth of the cutting insert also increases with increase in cutting forces. The ANOVA shows that the cutting insert shape is the most significant factor that contributes to the wear depth and cutting forces. YungChang Yen et.al [4] developed a methodology to forecast the tool wear progress and tool life using finite element simulations in orthogonal cutting operation. The DEFORM-2D software was used to develop the wear prediction procedure using Usui's wear model. The result predicted by the model was found to be underestimating the crater wear and flank wear rates compare to the measured values for the same tool life. The literature survey confirms that FEM software can be successfully used to study the effect of geometry of the tool on machining process. The geometry of the tool gets altered by the tool wear in particular by the flank wear. The flank wear land thought to be parallel to the cutting direction by some researchers $[10,11]$ and other believe that it makes a non zero angle with the cutting direction [12,13 \&14]. In recent times, experimental investigation conducted by Vishaldatt and S T Dundur [16] with a modified single point tool to capture the profile of flank wear land endorses the presence of nonzero inclination of the flank wear land with cutting direction. Authors study the effect of flank wear land inclination on the attributes of the orthogonal cutting using slip line field [17]. The results of the study shows that the flank wear land inclination has a significant effect on the cutting and thrust force and subsurface deformation below the flank wear land. Zhen Zhang [15] captured the non zero angle between the flank wear land and cutting direction by the white light Interferometry Microscope and found to be $3.8^{0}$ in that case. In the present study, finite element modeling and simulation of machining process used to know the effect of flank wear land length and its inclination on the cutting force, thrust force and distribution of velocity, effective stress and temperature.

\section{Finite Element Modeling}

The literature review shows that the commercial implicit coded DEFORM 2D is widely used to study the orthogonal machining [3,4,6-9]. Hence, in this study the orthogonal turning operation is performed by using DEFROM 2D software developed for large plastic deformation problems. The strength of the DEFROM 2D software lies in its capability to remesh finite elements automatically with dense grid of nodes around the tool tip to capture the small variations of temperature, strain and 
strain-rate. This approach eliminates the need of chip separation criterion, which makes DEFROM 2D a preferred software to simulate the metal cutting processes [6]. The pre-processor of the software uses a graphical user interface to assemble the data required to run the simulation. The geometry of the tool can be created or imported. The orthogonal cutting process is modeled as a plane strain problem which assumes the geometry to have a unit depth with both front and back faces constrained. Finite element meshes are created within the Deform environment using the automatic mesh generator. Based on complexity of geometry and governing criteria of the material behaviour an optimum mesh density is adopted automatically [18]. To perform a simulation, a database containing the process data and simulation controls is generated created processor module. The results of the simulation are displayed in graphical and alphanumeric form in post processor window.

The literature shows majority of the researchers [8, 9, 17] considered AISI 1045 (machining) steel for conducting orthogonal simulations. This has motivated the present work to consider the same type of steel as work piece material. Similarly the carbide $15 \%$ material is selected for the cutting tool. The coordinates of the primitive insert are edited to model the tool with different flank wear lengths and inclinations. The Figure1 shows the different tool geometries modeled in the DEFORM 2D pre-processor. The standard size of work piece is selected. The tool and work piece are meshed with 750 and 1500 elements.

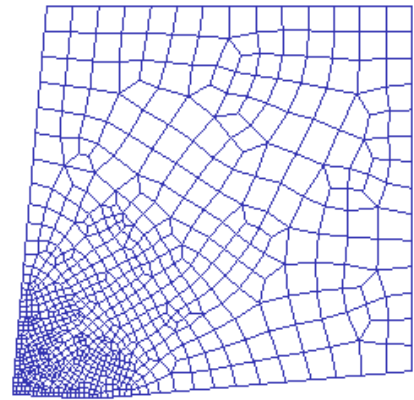

(a)

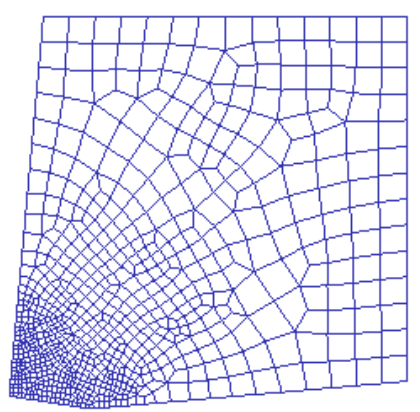

(b)

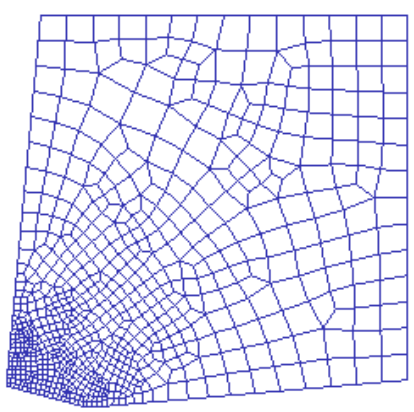

(c)

Figure 1: The worn tools with different flank wear land inclination a) $4^{0}$ b) $8^{0}$ c) $12^{0}$

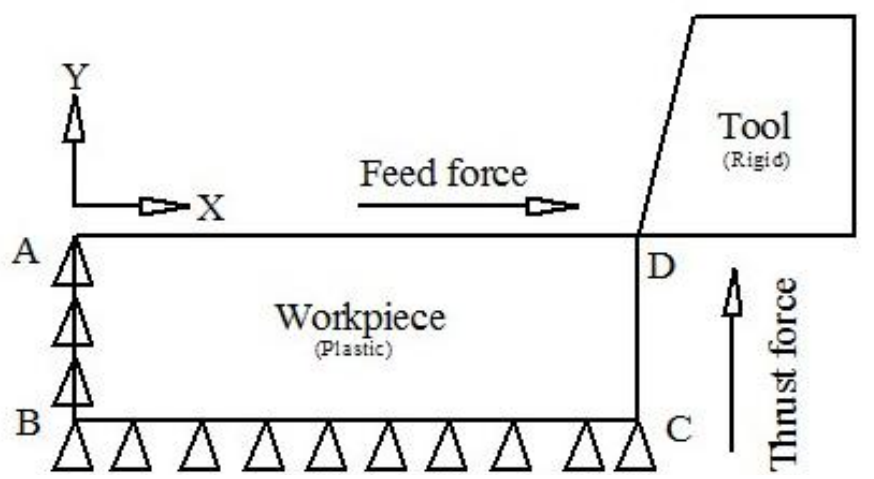

Figure 2: Boundary conditions 
The tool is considered as rigid body and workpiece as plastic body, which allows to determine the distribution of strain, strain rate, stress, temperature and nodal velocity. The Figure 2 shows the boundary conditions defined on the tool and workpiece. The workpiece is moved with constant cutting speed on the boundary $\mathrm{BC}$ against the stationary tool.

\section{Response Surface Method}

In order to investigate the influence of flank wear land inclination on the attributes of orthogonal machining response surface method (RSM) is used to model and analyze. The reason for selecting the response surface methodology is that, it discovers the interaction between several input variables with one or more response variables [19]. The required data to build the response model is obtained by simulation data. In this study, the compilation of simulation data is done by conducting trials as per the Central Composite Design (CCD) matrix. The ranges of the parameters are chosen based on the literature survey. The Table 1 shows the input parameters with their ranges.

The simulations are carried out in a constant cutting environment. (Cutting speed at $200 \mathrm{~m} / \mathrm{min}$, feed at $0.1 \mathrm{~mm} / \mathrm{rev}$, depth of cut at $0.5 \mathrm{~mm}$, Shear friction factor 0.8 and Heat transfer coefficient a $45 \mathrm{~N} / \mathrm{sec} / \mathrm{mm} / \mathrm{C}$. the length of workpiece as $3 \mathrm{~mm}$.) The simulations are carried out as per predetermined conditions based on the face centred CCD. The Table 2 gives the complete plan of simulation runs carried out with their responses. Analysis of Variance is used for recognizing the factors that affects the performance measures significantly.

Table 1: Input parameters and their ranges.

\begin{tabular}{clccccc}
\hline S1 no & \multicolumn{2}{c}{ Parameters Description } & \multicolumn{3}{c}{ Levels } \\
& Factors & Notation & Unit & High (+1) & Middle (0) Low (-1) \\
\hline 1 & Wear land & A & Mm & 6 & 4 & 2 \\
2 & $\begin{array}{l}\text { Flank wear land } \\
\text { inclination }\end{array}$ & B & Degrees & 8 & 4 & 2 \\
& & & & & \\
\hline
\end{tabular}

Table 2 Design matrix of simulations and Responses

\begin{tabular}{|c|c|c|c|c|c|c|}
\hline \multirow{3}{*}{$\begin{array}{c}\text { Std } \\
\text { Order }\end{array}$} & \multicolumn{4}{|c|}{ Process Parameters } & \multicolumn{2}{|c|}{ Responses } \\
\hline & \multicolumn{2}{|c|}{ Coded } & \multicolumn{2}{|c|}{ Un coded } & \multirow[b]{2}{*}{$\begin{array}{l}\text { Cutting } \\
\text { Force } \\
\mathrm{F}_{\mathrm{X}}[\mathrm{N}]\end{array}$} & \multirow[b]{2}{*}{$\begin{array}{l}\text { Thrust } \\
\text { Force } \\
\mathrm{F}_{\mathrm{Y}}[\mathrm{N}]\end{array}$} \\
\hline & $\begin{array}{l}\text { Wear } \\
\text { land }\end{array}$ & $\begin{array}{l}\text { Flank } \\
\text { wear land } \\
\text { inclination }\end{array}$ & $\begin{array}{l}\text { Wear } \\
\text { land } \\
{[\mathrm{mm}]}\end{array}$ & $\begin{array}{l}\text { Flank wear } \\
\text { land } \\
\text { inclination } \\
\text { [Degrees] }\end{array}$ & & \\
\hline 1 & -1 & -1 & 2 & 4 & 315 & 364 \\
\hline 2 & 1 & -1 & 6 & 4 & 239 & 121 \\
\hline 3 & -1 & 1 & 2 & 12 & 507 & 441 \\
\hline 4 & 1 & 1 & 6 & 12 & 355 & 603 \\
\hline 5 & -1 & 0 & 2 & 8 & 313 & 472 \\
\hline 6 & 1 & 0 & 6 & 8 & 326 & 574 \\
\hline 7 & 0 & -1 & 4 & 4 & 299 & 359 \\
\hline 8 & 0 & 1 & 4 & 12 & 449 & 530 \\
\hline 9 & 0 & 0 & 4 & 8 & 311 & 498 \\
\hline 10 & 0 & 0 & 4 & 8 & 311 & 498 \\
\hline 11 & 0 & 0 & 4 & 8 & 311 & 498 \\
\hline 12 & 0 & 0 & 4 & 8 & 311 & 498 \\
\hline 13 & 0 & 0 & 4 & 8 & 311 & 498 \\
\hline
\end{tabular}




\section{Results and Discussions}

The combination of the input parameter, flank wear land length and flank wear land inclination along with their responses are fed into standard statistical software package MINITAB to carry out the analysis of variance. The coefficient of regression analysis for cutting force is given in Table 3 along with linear, higher order and interactions between input parameters. The $p$ values are the indication of the significance of the term in regression analysis. The terms with $\mathrm{p}$ values $<0.05$ are significant. According to this higher order term of the flank wear land inclination is significant compare to all other terms. The terms $\mathrm{S}, \mathrm{R}^{2}$ and $\mathrm{R}^{2}$ (adj) indicates the anticipated standard deviation with reference to the regression line, coefficient of determination and approximate unbiased estimate of population respectively. The higher value of $\mathrm{R}^{2}$ needed to estimate the regression coefficients. In this analysis its value is higher i.e. $89.6 \%$. In present regression analysis, value of $\mathrm{R}^{2}(89.6 \%)$ is close to the value of $\mathrm{R}^{2}$ (adj) value $(82.2 \%)$. This closeness indicates the appropriateness of model. The flank wear land inclination has a significant effect on the cutting force. The estimated regression coefficients for thrust force are depicted in Table 4 the linear, higher order and interaction with wear land terms of the flank wear land inclination found to be more important as their $\mathrm{p}$ values are below 0.05 . The higher value of $\mathrm{R}^{2}(91.1 \%)$ indicates the statistical data obtained from simulation is significant. The flank wear land inclination has a non linear relationship with the cutting force and thrust force. The higher $\mathrm{R}^{2}$ value of thrust force compare to cutting force shows that the variables have more effect on thrust force than cutting force.

The main effects of variable on the cutting force and thrust force are shown in Figures 3(a) and (b). The cutting force decrease with increase in the wear land width this is because as larger width provides more area to resist the force coming on the tool. The flank wear land inclination at initial stage does not affect the cutting force

Table 3: Response Surface Regression:

Cutting force versus A (wear land), B (Flank wear land inclination)

\begin{tabular}{ccccc}
\hline Term & Coef & SE coef & $\mathrm{T}$ & $\mathrm{P}$ \\
\hline Constant & 333.712 & 97.013 & 3.440 & 0.011 \\
$\mathrm{~A}$ & 11.493 & 38.543 & 0.298 & 0.774 \\
$\mathrm{~B}$ & -20.640 & 19.272 & -1.071 & 0.320 \\
$\mathrm{~A} * \mathrm{~A}$ & -1.294 & 4.396 & -0.294 & 0.777 \\
$\mathrm{~B} * \mathrm{~B}$ & 3.078 & 1.099 & 2.801 & 0.026 \\
$\mathrm{~A} * \mathrm{~B}$ & -2.379 & 1.826 & -1.303 & 0.234 \\
\hline $\mathrm{S}=29.22$ & $\mathrm{R}-\mathrm{sq}=89.6 \%$ & \multicolumn{2}{c}{ R-sq $(\operatorname{adj})=82.2 \%$} \\
\hline
\end{tabular}

Table 4 Response Surface Regression:

Thrust force versus A(wear land), B(Flank wear land inclination )

\begin{tabular}{ccccc}
\hline Term & Coef & SE coef & T & P \\
\hline Constant & 213.384 & 158.657 & 1.345 & 0.221 \\
A & -65.321 & 63.034 & -1.036 & 0.335 \\
B & 75.683 & 31.517 & 2.401 & 0.047 \\
A*A & -4.282 & 7.189 & -0.596 & 0.57 \\
B*B & -5.995 & 1.797 & -3.336 & 0.012 \\
A*B & 12.658 & 2.987 & 4.238 & 0.004 \\
\hline $\mathrm{S}=47.79$ & R-sq $=91.1 \%$ & \multicolumn{2}{c}{ R-sq (adj) $=84.8 \%$} \\
\hline
\end{tabular}




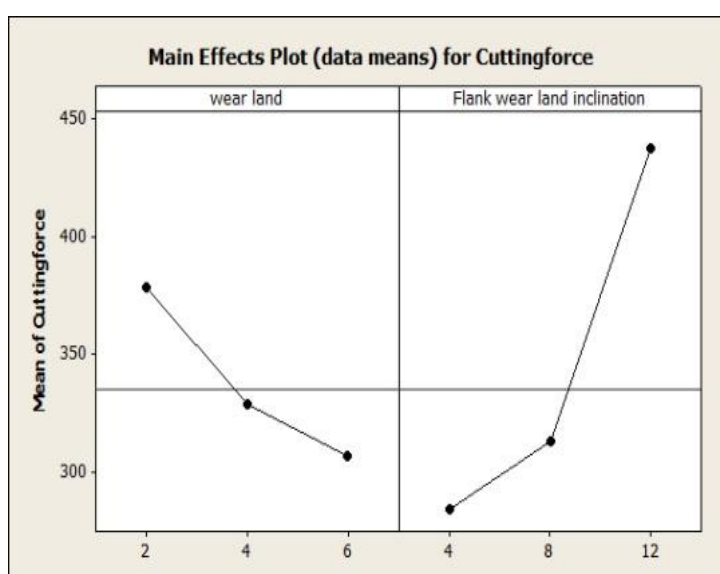

(a)

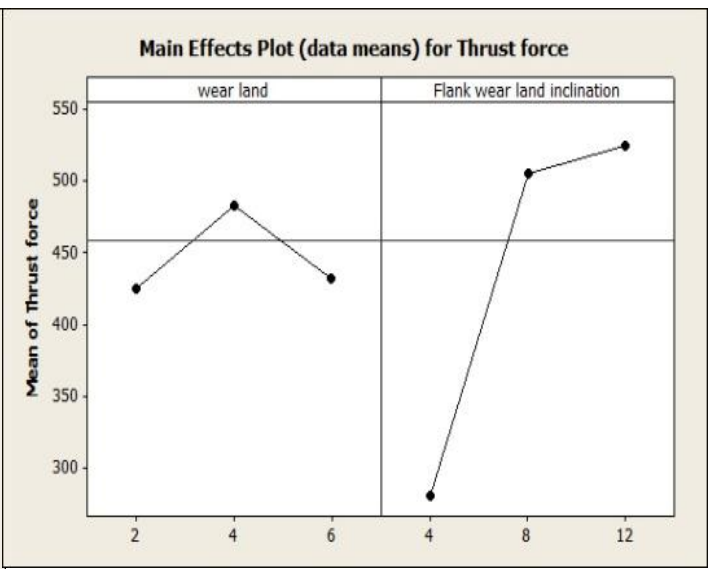

(b)

Figure 3: Main effects plot obtained from MINITAB (a) Cutting force (b) Thrust force

A small change in the value of angle at later stage has considerable effect on the cutting force. This observation is confirmed by the steep slope of the curve between cutting force and flank wear land inclination ( between $4^{0}$ to $8^{0}$ ). The Figure 3(b) shows that initially the thrust force increases with wear land and later on decreases with increase in the wear land. The flank wear land inclination shows reverse effect on thrust force when compare to cutting force. As small change in the flank wear land angle has a considerable effect on the thrust force at lower values.

The contour plot Figure 4 shows the interactive effect of wear land and flank wear land inclination on the cutting force. The wear land does not have much influence on cutting force at lower values of the flank wear land inclination. At this condition tool will be having lower degree of bluntness which is reflected in terms of lower values of cutting force. As the angle increases the cutting force increases, this is because of increase in bluntness of the tool.

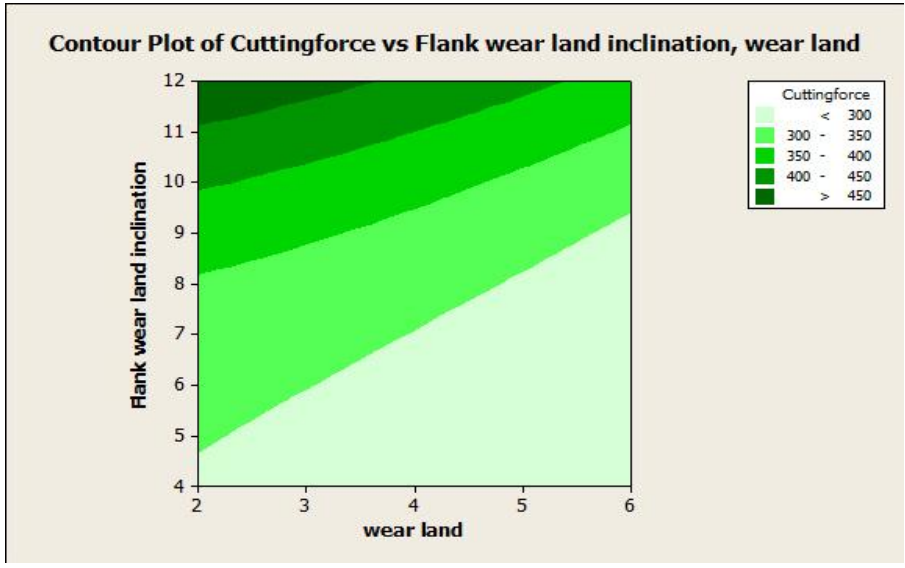

Figure 4: Contour plot between cutting force vs Flank wear land inclination, wear land

From the Figure 5 we find that at lower values of flank wear land inclination the width of wear land has significant influence on the thrust force. The higher values of wear land and its inclination give rise to higher values of the thrust force. The plot shows that there lies a range of flank wear land inclination angle 


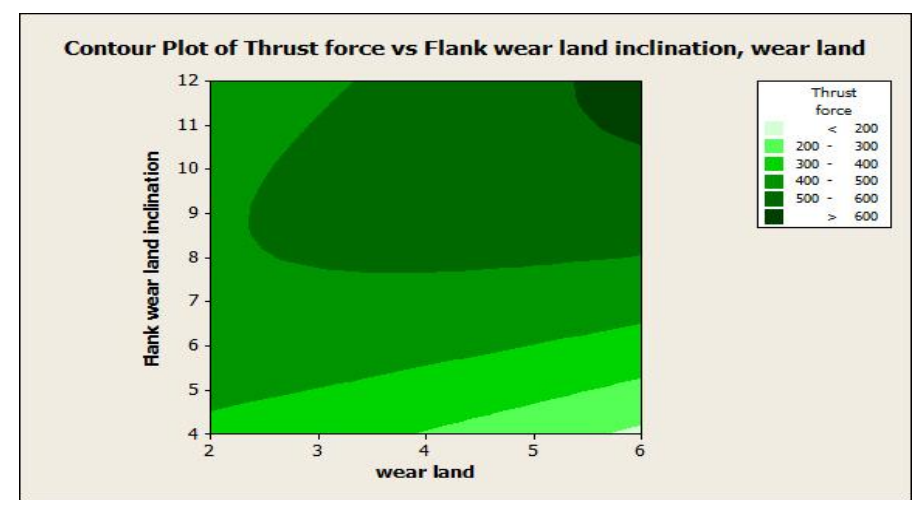

Figure 5: Contour plot between thrust force vs Flank wear land inclination, wear land

$\left(5^{0}\right.$ to $\left.8^{0}\right)$ where thrust force does not get affected by the width of wear land. The flank wear land inclination has more influence on the thrust force than the width of wear land. The main aim of the response surface methodology is to determine the optimum response. If the responses are more than one, then it finds conciliation optimum response considering all the responses. The other aim of RSM is to generate graphs to visualize direction of change of response, which enables to adjust the input variables as per the requirement [20]. In the present work the combination input and responses are used to study the distribution of various parameters like velocity, temperature stress and strain. DEFORM 2D's Post processor, which has graphical interface is used to study the effect of predetermined combination of input parameters on the responses. The Figure 6 (a to c) shows the total velocity distribution for trial 7 and trial $8 \mathrm{CCD}$ matrix. The Figure 6(a) shows the total velocity distributes approximately within the shear zone. This is so because the tool geometry has low level of wear land and low level of flank wear inclination angle (almost sharp tool). The velocity contour has higher values below the flank wear land and in Figure 6(c) it is very close to the velocity of the workpiece. This is an indication of existence of considerable amount of friction between the tool flank and machined surface. Similar condition was observed by [8] while machining with chamfer tool. It acknowledges the consideration of adhesion friction condition considered at interface of flank surface and machined surface while developing the slip line field with flank wear land by the authors in their study [21]. It can be seen from the Figure 6 (b) and (c) that, in both cases the wear land is same where as in (b) the angle is low level. The maximum total velocity occurs at the end of the wear land where as in (c), where the angle is at high level led to the shift in the position of maximum velocity position to beyond the flank face The temperature distribution in the tool is effect by both the input parameters -wear land and flank wear land inclination Figure 7 ( $a$ and $b$ ). The wear land for the trials 3 and 5 is same and angles are in the ascending order of levels. The highest temperature $\left(952^{\circ} \mathrm{C}\right)$ among the considered trials is observed when them temperature $\left(713^{0} \mathrm{C}\right)$ is observed when the 


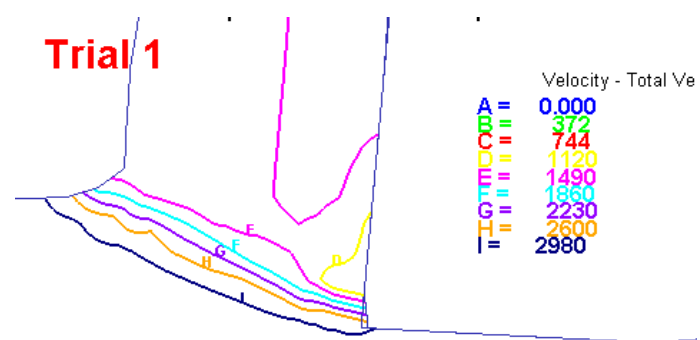

(a) Flank wear land inclination $=4$, Wear land $=2 \mathrm{~mm}$

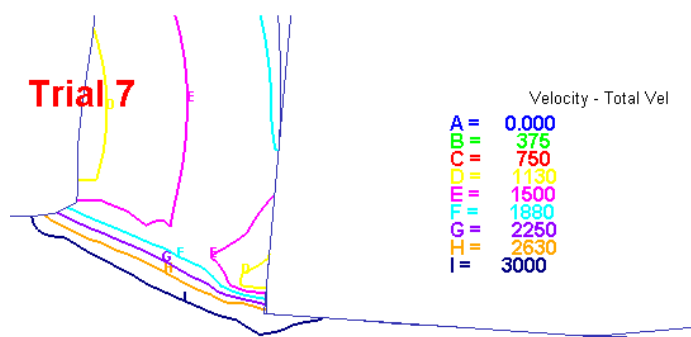

(b) Flank wear land inclination $=4$, Wear land $=4 \mathrm{~mm}$

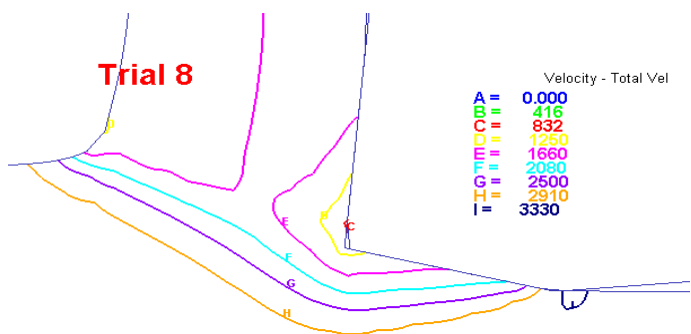

(c) Flank wear land inclination $=12$, Wear land $=4 \mathrm{~mm}$

Figure 6 Velocity distribution

angle is at the high level. The variation in the contact area between tool and workpiece is conscientious for it. If you consider the trials 3 and 4 the flank wear land inclination is same for both trials, at high level. Whereas wear land length is in ascending order of levels. It is observed that, the minimum temperature occurs when the wear land is at high level and maximum temperature occurs when wear land is at low level. With higher wear land more area is available for the heat transfer, hence the temperature is low. This kind of observation was reported while machining with the chamfer tool by the previous researchers [8]. From the above discussion it can be concluded that, there lies an optimum value of wear land and flank wear land inclination which can give the optimum performance of the tool.

The influence of wear land and flank wear land inclination on effective stress distribution is shown in Figure 8 ( $a$ and $b$ ). From the pictures it can be observed that the effective stress is accumulated near the flank wear land and its value is close to the maximum effective stress. This is another indication of the presence more friction between flank face and work interface [8]. Figure 8 (a and b) shows maximum value of effective stress augments towards the centre of the shear zone (contour line I) because of strain and 
strain hardening. It is also observed that the maximum effective stress lies in a zone which resembles the shape found in literature.

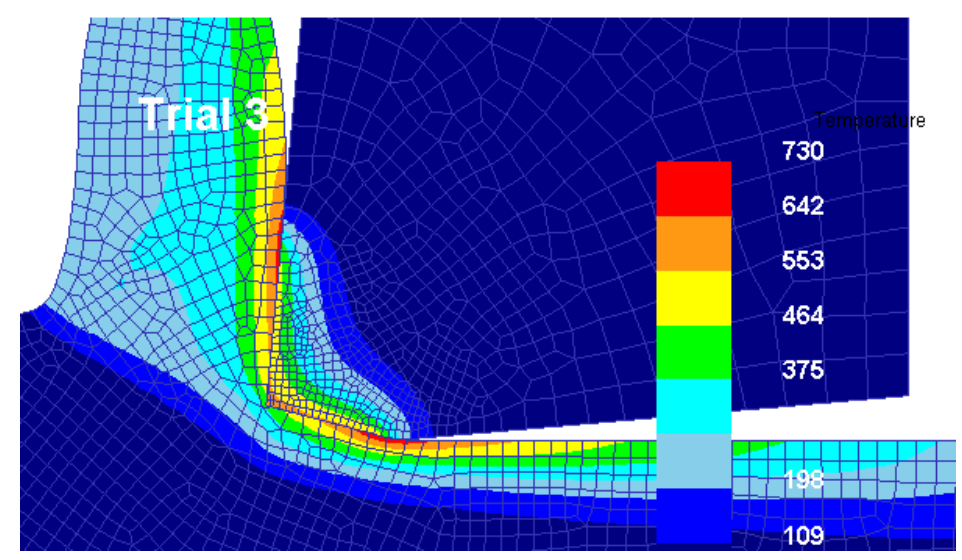

Figure 7(a) Flank wear land inclination $=12^{0}$, Wear land $=2 \mathrm{~mm}$

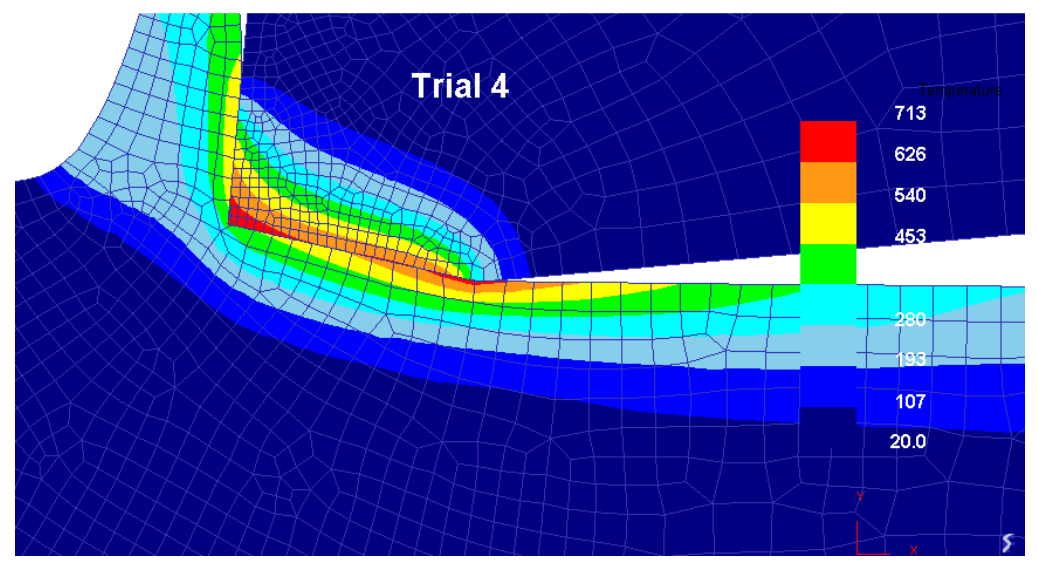

(b) Flank wear land inclination $=12^{0}$, Wear land $=6 \mathrm{~mm}$

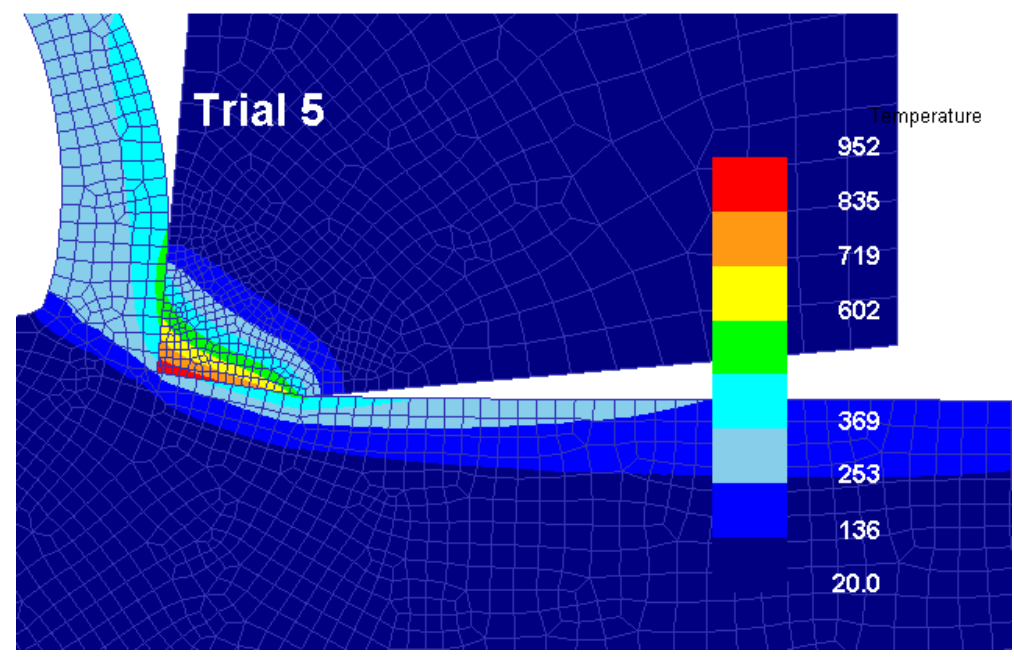

(c) Flank wear land inclination $=8^{0}$, Wear land $=2 \mathrm{~mm}$

Figure 7 Temperature distribution 


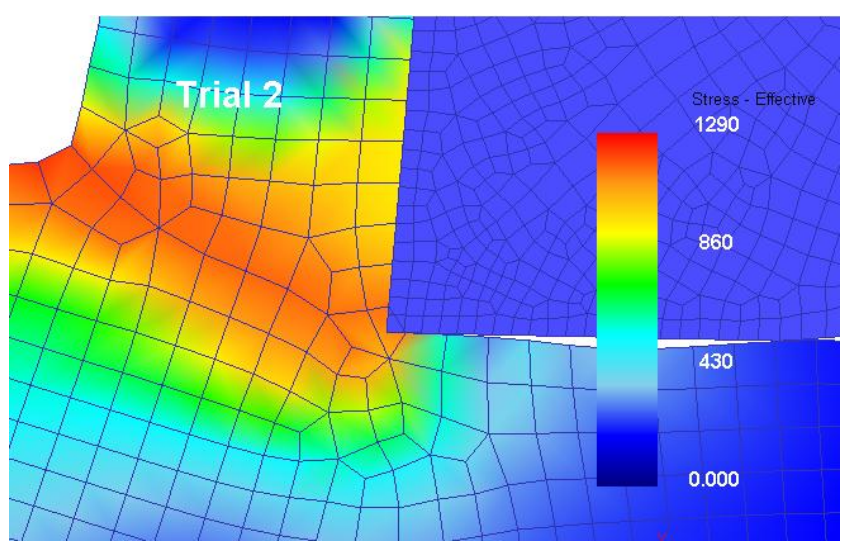

(a) Flank wear land inclination $=40$, Wear land $=6 \mathrm{~mm}$

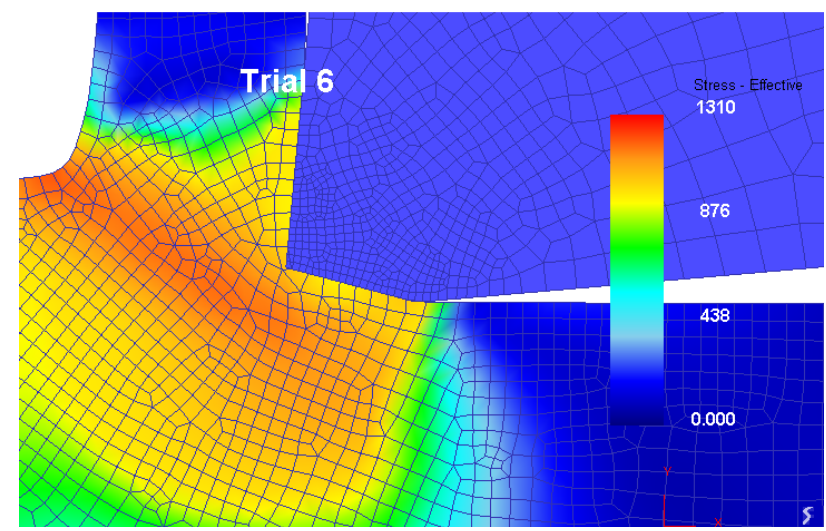

(b) Flank wear land inclination $=8^{0}$, Wear land $=6 \mathrm{~mm}$

Figure 8 Effective stresses distribution

\section{Conclusions}

The effect of flank wear land inclination with the machining direction on the aspects of orthogonal cutting has been studied using FEM tool. DEFORM 2D is used to model the tool with different flank

- At smaller inclination, the wear land length has no bearing on cutting force which may be attributed to sharpness of tool.

- The flank wear land inclination has higher influence on the thrust force compare to wear land length.

- With increase in the flank wear land inclination, the friction between flank face and machined surface increases. wear land inclinations and simulations are executed as per the Response Surface Method.. The effect of flank wear land inclination on cutting force and thrust force are studied.

- The temperature distribution depends on the flank wear land length and its inclination with the cutting direction.

The observations made in the present work will help to have better understanding of the machining with edge prepared tools where the conditions will be analogous to machining with flank wear. 


\section{References}

[1] Trent E and Paul Wright, Metal cutting,

Fourth

Edition,2000,Boston Oxford Auckland Johannesburg Melbourne New Delhi

[2] O.C. Zienkiewicz,The finite element method: Its basics and Fundamentals ,Sixth edition,2005, Elsevier Butterworth-Heinemann Linacre

[3] Nicoleta Lungu and Marian Borzan, Effect of cutting speed and feed rate on tool geometry, temperature and cutting forces in machining AISI 1045 carbon steel using FEM simulation, Proceedings in Manufacturing Systems, Vol. 7, Issue 4, 2012,pp 245-255

[4] Yung-Chang Yen, Jörg Söhner , Blaine Lilly , Taylan Altan, Estimation of tool wear in orthogonal cutting using the Finite element analysis, Journal of Materials Processing Technology, Vol.146, 2004,pp 82-91

[5] N S Das and S T Dundur, "Slip line field solutions for metal machining with adhesion friction and elastic effects at the chip tool contact region", Proceedings IMechE Part B:Journal of Engineering Manufacturing, Vol.219:Part B, 2005;pp. 57-72

[6] K. GÖK, A. GÖK and M. Erdem, Effect of friction coefficient in tool-workpiece interface during metal cutting, Engineering eTransaction (ISSN 1823-6379) Vol. 6, No. 1, June 2011, pp 32-3

[7] J.Zouhar and M.Piska, "Modelling the orthogonal machining process using cutting tools with different geometry", MM science journal, 2008,pp 48-51.

[8] K. Khalili \& M. Safaei, FEM analysis of edge preparation for chamfered tools, International journal of material forming. Vol. 2, Issue 4. 2009pp.217-224

[9] N. Senthil Kumar, T. Tamizharassan, Finite element analysis and optimization of uncoated carbide cutting inserts of different tool geometries in machining AISI 1045 steel, Journal of Mechanical Sciences, Vol. 1, No. 1, 2011, pp. 37-47.

[10] Uysal A., Altan E., A New SlipLine Field Modeling of Orthogonal Machining for a Worn Tool, International Symposium on Models and Modeling Methodologies in Science and Engineering: MMMse 2011, Vol. 3, July 201,1pp. 193-198, 19-22

[11] Raja k Kountanya and William J Endres,, Flank wear of edged radiused cutting tools under ideal straight edged orthogonal conditions, Tran.of the ASME,vol.126, 2004,pp 496-504.

[12] NS DAS \& S T Dundur, Slip line field solutions for metal machining with adhesion friction and elastic effects at the chip tool contact region, Proc. IMECH vol 219 part B j. Engg. Manufacture.,2005,pp57-71

[13] Shi T. and Ramlingam S., Slip-line solution for orthogonal cutting with a chip breaker and flank wear, Intenational . Jouranal of Mechanical Science .,Vol. 33, No. 9, 1991pp 689-704 .

[14] Yu Long and Yong Huang, Combined effects of flank and crater wear on cutting force modeling in orthogonal machining -Part-1: model development, Machining science and technology, Machining Science and Technology: An Int. Journal, Vol. 14(1), 2010,pp. 1-23, 2010.

[15] Zhen Zhang, Slip line modeling of machining with worn blunt cutting tools, Michigan technological 
university publication, 2008, $\mathrm{PhD}$ thesis

[16] Vishal Datt Kohir, Suresh T Dundur, et.al, An Investigation of Flank Wear Land Inclination In Orthogonal Machining, Journal for Manufacturing science and Production ,Vol. 13, Issue 12,2013, Pages 25-29,

[17] Jaharah A.G, Wahid S.W, Che Hassan C.H, Nuawi M.Z, Mohd Nizam Ab Rahman, "The Effect of uncoated carbide tool geometries in turning AISI 1045 using Finite element analysis", European journal of scientific research, Vol. 28 No.2,2009,pp: 271-277

[18] DEFORM 2D, V8.0 . User's Manual Scientific Technologies Corporation, 2004,Columbus.

[19] Douglas C.Montgomery, "Design and Analysis of Experiments", John Wiley \&Sons (Asia) Pte.Ltd, 5 th edition.

[20] Nuran Bradley, The response surface methodology, master of science thesis, Indiana University South Bend

[21] Vishal Datt Kohir and S T Dundur, Influence of flank wear land inclination on attributes of orthogonal machining using slip line field, International Journal of Mechanical Engineering \& Technology (IJMET), Vol. 5, Issue 4, 2014,pp-23-30 